\title{
Validitas Pemeriksaan Complex Specific Antigen Mycobacterium tuberculosis Region of Difference 1-3 Metode Rapid Immunochromatography pada Sputum Penderita Tuberkulosis Paru
}

\author{
Nenny Gustiani, Ida Parwati, Anna Tjandrawati, Leni Lismayanti \\ Departemen Patologi Klinik Fakultas Kedokteran Universitas Padjadjaran \\ Rumah Sakit Dr. Hasan Sadikin Bandung
}

\begin{abstract}
Abstrak
Tuberkulosis (TB) paru merupakan masalah kesehatan global. Diagnosis tuberkulosis paru saat ini berdasarkan pemeriksaan mikroskopis basil tahan asam (BTA) pada sputum dengan pewarnaan Ziehl Nelseen, namun sensitivitasnya rendah. Pemeriksaan antigen TB metode rapid immunochromatography (ICT) adalah suatu tes yang cepat, mudah, praktis, dan tidak memerlukan keterampilan khusus. Tes ini mendeteksi antigen yang disekresi Mycobacterium tuberculosis yaitu early secretory antigenic target $6 \mathrm{kDa}$ protein (ESAT6), culture filtrate protein (CFP10), dan Mycobacterium protein tuberculosis (MPT64) yang disandi oleh gen region of difference (RD)1, $R D 2$, dan $R D 3$. Tujuan penelitian untuk mengetahui validitas antigen TB ICT dalam mendiagnosis tuberkulosis paru. Penelitian dilaksanakan September 2012-Maret 2013 di Rumah Sakit Dr. Hasan Sadikin Bandung. Bentuk penelitian adalah observasional deskriptif dengan rancangan penelitian potong lintang dan analisis uji diagnostik. Setiap spesimen sputum dilakukan pemeriksaan mikroskopis BTA dan antigen TB rapid ICT. Biakan M. tuberculosis pada medium Ogawa digunakan sebagai standar baku emas. Tes niasin dilakukan pada koloni yang tumbuh. Didapatkan 149 subjek penelitian, kelompok usia terbanyak pada usia 30-39 tahun. Hasil pemeriksaan biakan didapatkan 56 sampel tumbuh, 86 tidak tumbuh, dan 7 terkontaminasi. Sensitivitas dan spesifisitas pemeriksaan antigen TB rapid ICT masing masing adalah 95,7\% dan 87,2\%. Simpulan, pemeriksaan antigen TB rapid ICT mempunyai validitas yang tinggi, sehingga dapat digunakan sebagai alternatif pemeriksaan laboratorium untuk diagnosis TB paru. [MKB. 2014;46(4):241-46]
\end{abstract}

Kata kunci: Antigen TB rapid ICT, biakan M. tuberculosis, medium Ogawa, mikroskopis BTA

\section{Validity of Complex Specific Antigen Mycobacterium tuberculosis Region of Difference 1-3 Examination Rapid Immunochromatography Method in Sputum Pulmonary Tuberculosis Patient}

\begin{abstract}
Pulmonary tuberculosis (TB) is still a global health problem. The diagnosis of pulmonary tuberculosis is based on sputum smear microscopy for acid fast bacilli (AFB) using Ziehl-Neelsen staining. However, this method has low sensitivity. Tuberculosis antigen immunochromatographyrapid test (ICT) is a quick, easy, and practical test which does not require special skills. This test is used to detect the antigen secretion of early secretory antigenic target $6 \mathrm{kDa}$ protein (ESAT6), culture filtrate protein (CFP10)and Mycobacterium protein tuberculosis (MPT64) from Mycobacterium tuberculosis which are encoded by the region of difference (RD) $1, \mathrm{RD} 2$ and RD3 genes. The aim of this study was to determine the validity of TB antigen for the diagnosis of pulmonary tuberculosis. The study was conducted during the period of September 2012 to March 2013 in Dr. Hasan Sadikin General Hospital (RSHS) Bandung. This study is a descriptive observational study using cross sectional approach and validity analysis. From September 2012 until March 2013 there were 149 subjects, in which the dominant age group was 30-39 years. All the specimens were cultured on Ogawa medium as the gold standard and niasin tests were performed on all positive cultures. The TB antigen rapid ICT and sputum smear microscopy AFB were done on all the samples. From 149 subjects, 56 were positive, 86 were negative and 7 were contaminated. The sensitivity and specificity of TB antigen rapid ICT were $95.7 \%$ and $87.2 \%$, respectively. In conclusion, TB antigen rapid ICT has a high validity which can be used as alternative laboratory tests for screening in patients with suspected pulmonary tuberculosis. [MKB. 2014;46(4):241-46]
\end{abstract}

Key words: AFB smear, M. tuberculosis culture, Ogawa medium, TB antigen rapid ICT

Korespondensi: Nenny Gustiani, dr., Departemen Patologi Klinik Fakultas Kedokteran Universitas Padjadjaran/Rumah Sakit Dr. Hasan Sadikin Bandung J1. Pasteur No. 38 Bandung, mobile 08112272071, e-mail nennygustiani@gmail.com 


\section{Pendahuluan}

Tuberkulosis (TB) merupakan salah satu masalah kesehatan global yang utama. Pada tahun 2012 World Health Organization (WHO) melaporkan 9 juta kasus dan 1,4 juta kematian disebabkan oleh tuberkulosis. ${ }^{1}$ Penyakit yang disebabkan Mycobacterium tuberculosis complex ini biasanya menginfeksi organ paru (TB paru), tetapi dapat juga menginfeksi organ lainnya (TB ekstraparu). Sumber penularan TB ini adalah penderita TB dengan basil tahan asam (BTA) positif. Penderita TB paru BTA positif dapat mengeluarkan bakteri M. tuberculosis dalam bentuk droplet ke udara pada waktu penderita sedang batuk dan bersin sehingga menjadi sumber penularan kepada orang di sekitarnya. Penegakan diagnosis yang cepat dan tepat serta pengobatan dini pada penderita TB merupakan suatu upaya dalam pencegahan dan penyebaran tuberkulosis lebih lanjut, serta merupakan kunci utama dalam penanggulangan TB. ${ }^{2}$

Pemeriksaan laboratorium untuk mendiagnosis TB paru saat ini memiliki keterbatasan, misalnya sensitivitas mikroskopis BTA rendah, metode biakan membutuhkan waktu lama, atau metode molekuler yang memerlukan keahlian khusus. Metode biakan sputum merupakan metode baku emas (gold standard) untuk TB paru, namun pemeriksaan biakan memerlukan waktu lama yaitu 6-8 minggu. ${ }^{2}$ Uji serologi untuk mendeteksi antibodi $M$. tuberculosis dengan metode rapid immunochromatography (ICT) sudah banyak dilakukan. Pada tahun 2011, WHO menerbitkan policy statement yang merekomendasikan untuk tidak menggunakan reagen komersial deteksi antibodi karena sensitivitas rendah dan bervariasi antara $1 \%$ sampai $60 \%$ dan spesifisitas $53-99 \% .^{3,4}$ Metode diagnostik yang mudah, cepat, dan akurat diperlukan untuk memperbaiki diagnosis dan meningkatkan efisiensi pengendalian TB dalam menanggulangi berbagai keterbatasan tersebut.

Berbagai bahan pemeriksaan untuk mendeteksi antigen tuberkulosis telah dikembangkan melalui temuan antigen spesifik yang berasal dari protein yang disekresi oleh $M$. tuberculosis. Antigen protein tersebut adalah early secretory antigenic target $6 \mathrm{kDa}$ protein (ESAT6), culture filtrate protein (CFP10), dan Mycobacterium protein tuberculosis (MPT64), yang disandi oleh gen regions of difference $(\mathrm{RD}) 1$, RD2, dan RD3. Ketiga antigen tersebut disekresi oleh $M$. tuberculosis saat bakteri hidup. Terdapatnya antigen ini pada spesimen sputum penderita merupakan penanda terjadi infeksi tuberkulosis paru aktif. ${ }^{5-7}$

Suatu penelitian tentang genom komparatif yaitu penguraian sekuens genom $M$. tuberculosis dan juga analisis komparatif dengan spesies mikobakteria yang lain telah banyak membantu yang mengungkapkan bahwa beberapa regio genom (RD1, RD2, dan RD3) terdapat pada M. tuberculosis complex tetapi terdelesi pada substrain M. bovis Bacillus Calmette-Guerin (BCG) dan absen pada sejumlah Mycobacterium other than tuberculosis (MOTT). Keberadaan RD1-RD3 pada genom M. tuberculosis, M. bovis, dan juga $M$. bovis BCG dapat dideteksi dengan memakai metode hibridisasi genom substraktif dan dikonfirmasi dengan cara membandingkan physical map strain BCG dengan kromosom $M$. tuberculosis. Gen yang menyandi ESAT6, CFP10, dan MPT64 terdapat pada regio RD yang terdelesi ini sehingga RD1-RD3 diduga kuat sebagai gen virulensi yang dimiliki oleh $M$. tuberculosis. ${ }^{3,8-11}$

Saat ini telah dikembangkan suatu metode pemeriksaan ICT yang cepat, mudah praktis, dan tidak memerlukan keahlian khusus untuk mendeteksi antigen TB. Bahan untuk mendeteksi antigen TB pada alat ini menggunakan kombinasi dari tiga antibodi monoklonal terhadap antigen spesifik ESAT6, CFP10, dan juga MPT64 yang diekskresikan $M$. tuberculosis pada masa aktif. Pemeriksaan antigen TB rapid ICT ini mempergunakan spesimen sputum tersangka penderita tuberkulosis paru. Tujuan penelitian ini untuk mengetahui validitas pemeriksaan complex specific antigen RD1-RD3 (ESAT6, CFP10, dan MPT64) pada sputum penderita TB paru dengan menggunakan metode rapid ICT sebagai penanda diagnosis TB paru.

\section{Metode}

Penelitian ini dilakukan dalam periode September 2012-Maret 2013 di Laboratorium Mikrobiologi Klinik Departemen Patologi Klinik Rumah Sakit Dr. Hasan Sadikin (RSHS) Bandung. Bentuk penelitian adalah analitik observasional deskriptif dengan rancangan penelitian potong lintang yaitu uji validitas pemeriksaan antigen TB rapid ICT terhadap baku emas biakan M. tuberculosis pada media Ogawa. Subjek penelitian adalah penderita usia $>14$ tahun yang telah didiagnosis secara klinis sebagai suspek tuberkulosis paru berdasarkan International Standard of Tuberculosis (ISTC) dan pedoman TB Nasional, yang datang ke Poliklinik Pulmonologi atau Poliklinik Directly Obserbved Treatment Short-Course (DOTS) di RSHS. Penderita TB dengan hasil biakan rusak atau kontaminasi berat dan juga spesimen yang tidak memungkinkan untuk diulang, dieksklusi dari subjek penelitian. Bahan pemeriksaan yang dipergunakan yaitu berupa spesimen sputum yang ditampung ke dalam pot sputum pada tiga waktu (sewaktu-pagi-sewaktu). 
Cara pemeriksaan antigen $\mathrm{TB}$ rapid $\mathrm{ICT}$ menggunakan spesimen sputum adalah larutan bufer sebanyak $200 \mu \mathrm{L}$ yang dimasukkan ke dalam pot yang berisi sputum, kemudian diaduk mempergunakan pipet plastik selama 30-60 detik dan inkubasi minimal 30 menit. Dengan mempergunakan pipet plastik, teteskan 4 tetes $( \pm 200 \mu \mathrm{L})$ larutan sampel ke cassete tes (pada area $\mathrm{S}$ ). Interpretasi hasil dilakukan setelah 15 menit. Interpretasi hasil pemeriksaan antigen TB rapid ICT dilakukan oleh tiga orang pemeriksa, yang bertujuan untuk dapat menghilangkan faktor subjektivitas, maka hasil pemeriksaan antigen TB rapid ICT pada 30 sampel pertama dianalisis tentang kesesuaian antarpemeriksa (interobserver disagreement) prapenelitian terlebih dahulu dalam menentukan hasil pemeriksaan antigen TB rapid ICT yang bersifat kualitatif dengan menghitung indeks kappa (к). Nilai kappa yang ideal adalah 1 , namun nilai $>0,8$ biasanya dianggap sangat baik. Hasil pengujian interobserver pemeriksaan antigen TB rapid ICT antara observer 1 dan 2 didapatkan indeks kappa sebesar 1,0. Indeks kappa antara observer 2 dan 3 sebesar 1,0 dan antara observer 1 dan 3 sebesar 1,0 dengan $p=0,001$ $(\mathrm{p}<0,05$ bermakna). Prapenelitian ini didapatkan kesesuaian yang tinggi di antara observer dalam menilai pemeriksaan antigen TB rapid ICT secara kualitatif. Analisis statistik yang digunakan untuk uji validitas ini adalah menghitung sensitivitas, spesifisitas, nilai prediksi positif (NDP), nilai prediksi negatif (NDN), dan akurasi melalui tabel $2 \times 2$.

\section{Hasil}

Selama kurun periode penelitian ini, didapatkan 149 subjek penelitian. Dari semua subjek yang didapatkan tidak semuanya dianalisis uji validitas karena terdapat 7 subjek yang dieksklusi dari penelitian (Gambar 1).

Tabel 1 Karakteristik Subjek

\begin{tabular}{|c|c|c|}
\hline Variabel & $\mathbf{n}$ & $\%$ \\
\hline \multicolumn{3}{|l|}{ Jenis kelamin } \\
\hline Laki-laki & 75 & 50,4 \\
\hline Perempuan & 74 & 49,6 \\
\hline \multicolumn{3}{|l|}{ Usia kategori (tahun) } \\
\hline$<20$ & 12 & 8,0 \\
\hline $20-29$ & 31 & 20,8 \\
\hline $30-39$ & 37 & 24,8 \\
\hline $40-49$ & 25 & 16,8 \\
\hline $50-59$ & 30 & 20,2 \\
\hline$\geq 60$ & 14 & 9,4 \\
\hline \multicolumn{3}{|l|}{ Median: 37,5} \\
\hline \multicolumn{3}{|l|}{ Rentang: 14-82 } \\
\hline \multicolumn{3}{|l|}{ Gejala klinis } \\
\hline Batuk berdahak & 149 & 100 \\
\hline Sesak & 43 & 28,8 \\
\hline Riwayat merokok & 79 & 53 \\
\hline \multicolumn{3}{|l|}{ Hasil rontgen toraks } \\
\hline Mendukung TB & 83 & 55,7 \\
\hline Tidak mendukung TB & 66 & 44,3 \\
\hline \multicolumn{3}{|c|}{ Pemeriksaan kikroskopis BTA } \\
\hline BTA negatif & 90 & 60,4 \\
\hline BTA positif & 59 & 39,6 \\
\hline Jumlah & 149 & 100 \\
\hline
\end{tabular}

Keterangan: $\mathrm{TB}=$ tuberkulosis; $\mathrm{Ag}=$ antigen; $\mathrm{BTA}=$ basil tahan asam 


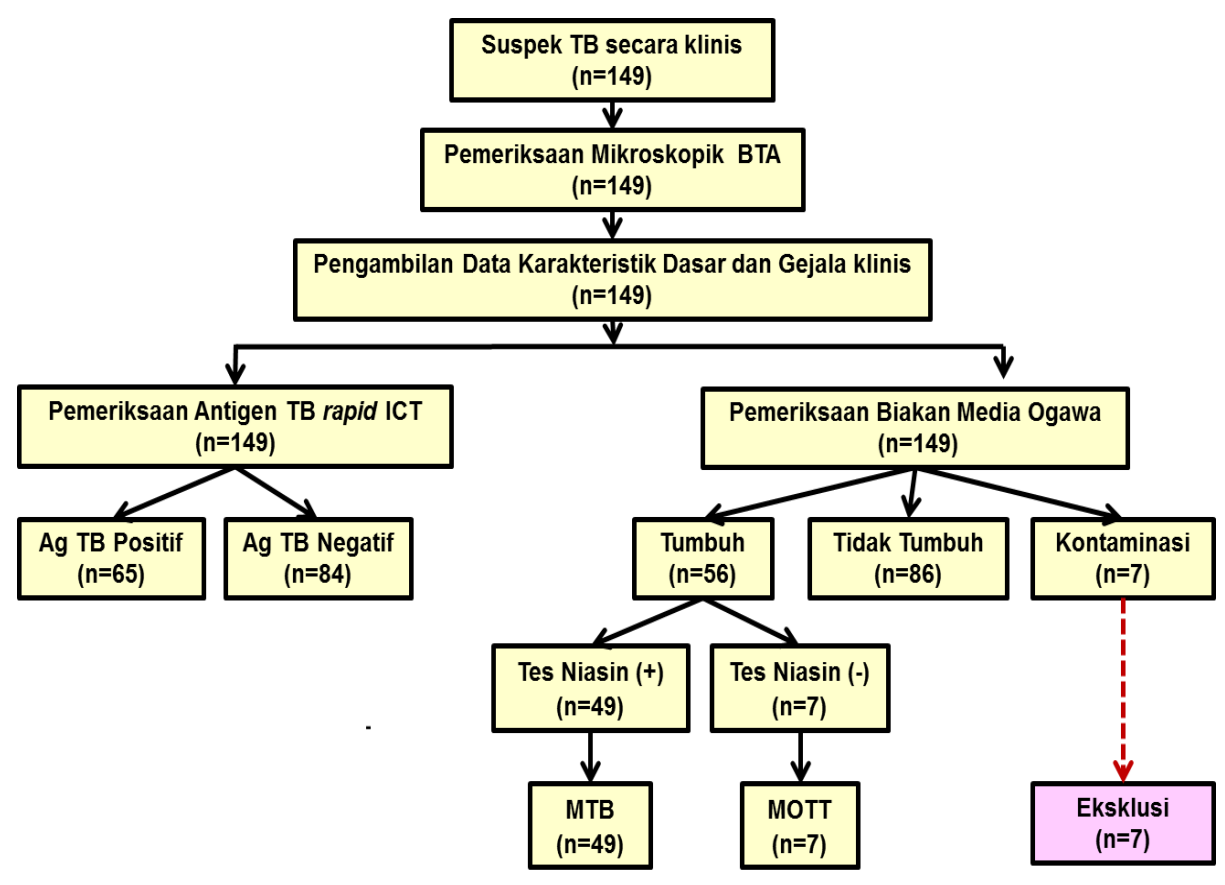

\section{Gambar 1 Bagan Penelitian}

Keterangan: TB=tuberkulosis; Ag=antigen; ICT=immunochromatography; ZN (Ziehl Neelsen);

$\mathrm{BTA}=$ basil tahan asam; MOTT=Mycobacteria other than tuberculosis;

$\mathrm{MTB}=$ Mycobacterium tuberculosis complex

Sebanyak 7 dari 149 sampel hasil biakan M.tuberculosis padamedia Ogawa terkontaminasi, sehingga tidak dapat dilakukan pemeriksaan niasin dan dieksklusi dari penelitian. Pada biakan yang tumbuh koloni dengan hasil tes niasin positif menandakan terdapat spesies $M$. tuberculosis, sedangkan biakan yang tumbuh koloni dengan hasil tes niasin negatif yang menandakan spesies MOTT. Jumlah sampel yang akan dianalisis uji validitas sebanyak 142 sampel. Hasil uji validitas antigen TB rapid ICT terhadap baku emas biakan M. tuberculosis menunjukkan sensitivitas 95,9\%;

\section{Tabel 2 Hasil Pemeriksaan Biakan M. tuberculosis pada Media Ogawa dan Antigen TB Rapid} ICT

\begin{tabular}{lccc}
\hline \multicolumn{1}{c}{ Variabel } & $\mathbf{n}$ & $\mathbf{\%}$ & Interpretasi \\
\hline Hasil pemeriksaan biakan media Ogawa $(\mathrm{n}=149)$ & & & \\
$\quad$ Tidak ada pertumbuhan & 86 & 57,7 & Biakan negatif \\
$\quad$ Tumbuh & 56 & 37,6 & Biakan positif \\
$\quad$ Kontaminasi & 7 & 4,7 & \\
Hasil pemeriksaan niasin pada koloni yang tumbuh & & & M. tuberculosis \\
$(\mathrm{n}=56)$ & 49 & 87,5 & MOTT \\
$\quad$ Niasin positif & 7 & 12,5 & \\
$\quad$ Niasin negatif & & & \\
Hasil pemeriksaan antigen TB rapid ICT $(\mathrm{n}=149)$ & 58 & 50,8 & 59,2 \\
$\quad$ Antigen TB positif & 84 & & \\
$\quad$ Antigen TB negatif & & &
\end{tabular}

Keterangan: MOTT=Mycobacteria other than tuberculosis, $\mathrm{TB}=$ tuberkulosis, $\mathrm{CT}=$ immunochromatography test . Tes niasin positif menandakan spesies $M$. tuberculosis dan tes niasin negatif menandakan spesies MOTT 
spesifisitas 88,2\%; NDP 81,0\%; NDN 97,6\%; dan akurasi 90,8\%.

\section{Pembahasan}

Subjek penelitian ini sebagian besar adalah lakilaki. Berdasarkan kepustakaan penyakit TB lebih banyak terjadi pada laki-laki. ${ }^{12}$ Perbedaan jenis kelamin dan perilaku juga dapat memengaruhi perkembangan penyakit, misalnya merokok dan penyalahgunaan alkohol yang dapat menyebabkan imunitas tubuh menurun. ${ }^{13}$ Sebagian besar subjek penelitian berada pada kelompok usia 30-39 tahun $(24,8 \%)$. Penyakit TB dapat terjadi pada semua kelompok usia, tetapi yang tertinggi terjadi pada usia reproduktif yaitu usia 25-50 tahun. Penyakit TB paru akan mengalami perjalanan penyakit berupa infeksi primer yang kemudian pada usia dewasa atau usia reproduktif akan terjadi reaktivasi apabila terjadi imunitas yang menurun yang disebabkan oleh pekerjaan yang berat tanpa diimbangi dengan asupan gizi yang

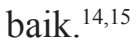

Pemeriksaan antigen TB rapid ICT dapat mendeteksi antigen RD1-RD3 (ESAT6, CFP10, dan juga MPT64) pada spesimen sputum yang menunjukkan infeksi $M$. tuberculosis complex. Selain itu, pemeriksaan antigen TB rapid ICT dapat membedakan $M$. tuberculosis complex dan MOTT, akan memberikan hasil positif pada $M$. tuberculosis complex, sedangkan pada MOTT memberikan hasil negatif.,

Uji validitas pemeriksaan antigen TB rapid ICT terhadap biakan M. tuberculosis pada media Ogawa, didapatkan sensitivitas antigen TB rapid ICT adalah 95,9\% dan spesifisitasnya adalah $88,2 \%$. Hasil yang didapat ini sedikit berbeda dengan beberapa penelitian serupa yang dilakukan oleh peneliti lainnya, seperti penelitian Aryati ${ }^{16} \mathrm{di}$ Surabaya yang mendapatkan sensitivitas sebesar $85 \%$ dan spesifisitas $90,9 \%$. Spesifisitas pada penelitian ini lebih rendah daripada sensitivitas karena 11 sampel tidak tumbuh pada media biakan. Sebanyak 11 sampel ini pemeriksaan antigen TB rapid ICT menunjukkan positif $M$. tuberculosis, namun ternyata biakan $M$. tuberculosis, hasilnya tidak tumbuh atau negatif. Hal ini merupakan negatif palsu biakan M. tuberculosis atau positif palsu pemeriksaan antigen TB rapid ICT. Setelah dilakukan penelusuran data dari medical record penderita sudah mendapatkan terapi antibiotik sebelum datang berobat ke Poliklinik Pulmonologi atau Poliklinik DOTS di RSHS yaitu golongan fluorokuinolon yang mengakibatkan viabilitas M. tuberculosis berkurang sehingga tidak dapat tumbuh dalam media biakan.

Sebanyak dua subjek penelitian memberikan hasil antigen TB rapid ICT negatif namun pada biakan media Ogawa hasilnya positif. Hasil ini merupakan negatif palsu pemeriksaan antigen TB rapid ICT. Kemungkinan penyebab negatif palsu pada penelitian ini yaitu jumlah BTA dalam spesimen sputum yang kurang. Pemeriksaan jenis rapid ICT mempunyai batas deteksi jumlah bakteri di dalam spesimen yang akan memberikan hasil positif. Menurut penelitian yang dilakukan Shen dkk. ${ }^{5}$ dinyatakan untuk mengidentifikasi ESAT6/ CFP10 oleh rapid ICT, diperlukan konsentrasi minimal M. tuberculosis di dalam isolat biakan sebanyak $3 \times 10^{4}$ sampai dengan $3 \times 10^{5} \mathrm{CFU} / \mathrm{mL}$, sedangkan metode biakan merupakan metode untuk menumbuhkan dan memperbanyak bakteri, maka dengan 500 BTA dapat menghasilkan biakan positif. Negatif palsu juga dapat disebabkan oleh karena kerusakan epitop dari antibodi rekombinan yang menjadi epitop penangkap antigen TB pada alat tersebut, sehingga menghasilkan tes yang negatif. Nilai negatif palsu ini akan memengaruhi nilai sensitivitas.

Dari 56 sampel biakan positif terdapat 7 sampel menunjukkan MOTT. Hal ini kemungkinan terjadi karena infeksi campuran dengan $M$. tuberculosis complex, atau dapat juga memang disebabkan oleh infeksi tunggal oleh MOTT karena MOTT ini dapat ditemukan dalam lingkungan seperti air, tanah, dan dapat membentuk kolonisasi pada kulit normal. Pertumbuhan MOTT lebih cepat dan mampu mendesak pertumbuhan $M$. tuberculosis complex, sehingga koloni MOTT lebih banyak tumbuh dibandingkan dengan $M$. tuberculosis complex. ${ }^{17,18}$

Sensitivitas pemeriksaan mikroskopis BTA dengan cara pewarnaan Ziehl-Neelsen didapatkan yaitu sebesar $85,7 \%$ dan spesifisitasnya $94,2 \%$. Sensitivitas pemeriksaan mikroskopis BTA menurut berbagai kepustakaan adalah $50-70 \%$ bahkan dapat lebih rendah. ${ }^{19}$ Keadaan ini sangat dipengaruhi karena kemampuan atau keahlian petugas di dalam membaca preparat, beban kerja yang banyak, serta cara pembuatan preparat dan pewarnaan yang baik, sehingga bila dibandingkan dengan pemeriksaan antigen TB rapid $\mathrm{ICT}$, maka pemeriksaan antigen TB rapid ICT mempunyai sensitivitas yang lebih baik daripada mikroskopis BTA. Pemeriksaan antigen TB rapid ICT dapat digunakan untuk mendeteksi $M$. tuberculosis terutama untuk skrining pada sputum penderita suspek tuberkulosis paru.

Keterbatasan penelitian ini mempergunakan metode biakan untuk $M$. tuberculosis yang bukan merupakan baku emas yang sempurna (imperfectl allowed gold standard) karena bila biakan $M$. tuberculosis negatif tidak dapat menyingkirkan diagnosis TB paru bila klinis dan pemeriksaan lainnya menunjang. Namun demikian, sampai 
saat ini berbagai macam kepustakaan menyatakan bahwa metode biakanlah yang merupakan baku emas yang direkomendasikan., ${ }^{2,20}$

Simpulan, pemeriksaan antigen tuberkulosis metode rapid immunochromatography terhadap bahan pemeriksaan sputum mempunyai validitas berupa sensitivitas yang tinggi dan spesifisitas yang sedang terhadap baku emas metode biakan M. tuberculosis pada media Ogawa.

\section{Daftar Pustaka}

1. WHO. Global tuberculosis control 2012: The burden of disease caused by TB. WHO Report. 2012: 9-12.

2. CDC. Core curricullum on tuberculosis: what the clinician should know. Center for Disease Control and Prevention. National Center for HIV/AIDS, Viral hepatitis, STD and TB Prevention. Division of Tuberculosis Elimination; 2011.

3. Parkash O, Singh BP, Pai M. Regions of differences encoded antigens as targets for immunodiagnosis of tuberculosis in humans. Scand J Immunol. 2009;70(4):345-57.

4. WHO. 2010/2011 TB global fact. Tuberculosis serodiagnostic tests policy statement 2011. Geneva: WHO; 2011.

5. Shen GH, Chiou CS, Hu ST, Wu KM, Chen JH. Rapididentification of the Mycobacterium tuberculosis complex by combining the ESAT-6/CFP-10 immunochromatographic assay and smear morphology. J Clin Microbiol. 2011;49(3):902-7.

6. Kumar VG, Urs TA, Ranganath RR. MPT 64 Antigen detection for rapid confirmation of M. tuberculosis isolates. BMC Res Notes. 2011;4:79.

7. Wang BL, Xu Y, Li ZM, Xu YM, Weng XH, Wang HH. Antibody response to four secretory proteins from Mycobacterium tuberculosis and their complex antigen in TB patients. Int J Tuberc Lung Dis. 2005;9(12):1327-34.

8. Lewis KN, Liao R, Guinn KM, Hickey MJ, Smith S, Behr MA, dkk. Deletion of RD1 from Mycobacterium tuberculosis mimics bacille Calmette-Guerin attenuation. J Infect Dis. 2003;187(1):117-23.

9. Renshaw PS, Lightbody KL, Veverka V, Muskett FW, Kelly G, Frenkiel TA. Structure and function of the complex formed by the tuberculosis virulence factors CFP-10 and ESAT-6. EMBO J. 2005;24(14):2491-8.
10. Ernst JD, Trevejo-Nunez G, Banaiee N. Genomics and the evolution, pathogenesis, and diagnosis of tuberculosis. J Clin Invest. 2007;117(7):1738-45.

11. Gao LY, Guo S, McLaughlin B, Morisaki $\mathrm{H}$, Engel JN, Brown EJ. A mycrobacterial virulence gene cluster extending RD1 is required for cytolysis, bacterial spearding and ESAT-6 secretion. Mol Microbiol. 2004;53(6):1677-93.

12. Bhat J, Rao VG, Gopi PG, Yadav R, Selvakumar N, Tiwari B, dkk. Prevalence of pulmonary tuberculosis amongst the tribal population of Madhya Pradesh, central India. Int J Epidemiol. 2009;38(4):1026-32.

13. Shin SS, Mathew TA, Yanova GV, Fitzmaurice GM, Livchits V, Yanov SA, dkk. Alcohol consumption among men and women with tuberculosis in Tomsk, Russia. Cent Eur J Public Health. 2010;18(3):132-8.

14. Sita-Lumsden A, Lapthorn G, Swaminathan R, Milburn HJ. Reactivation of tuberculosis and vitamin $\mathrm{D}$ deficiency: the contribution of diet and exposure to sunlight. Thorax. 2007;62(11):1003-7.

15. Smith I. Mycobacterium tuberculosis pathogenesis and molecular determinants of virulence. Clin Microbiol Rev. 2003;16(3):463-96.

16. Aryati. One step mycobacterium tuberculosis antigen rapid test. Dalam: Purwanto A, Hendro $\mathrm{P}$, penyunting. Continuing Professional Development on Laboratory Medicine; Joglosemar IV, 22-24 Juni 012: Perhimpunan Dokter Spesialis Patologi Klinik Cabang Semarang; 2012. hlm. 88-100.

17. Elhassan MM, Eltikeina AWY, Saleh RM, Elmekki MA, Hamid ME. Molecular detection of Mycobacterium other than tuberculosis among patients with pulmonary infection. Bahrain Med Bull. 2011;33(2):1-6.

18. De Groote MA, Huitt G. Infections due to rapidly growing mycobacteria. Clin Infect Dis. 2006;42(12):1756-63.

19. Fennelly KP, Morais CG, Hadad DJ, Vinhas S, Dietze R, Palaci M. The small membrane filter method of microscopy to diagnose pulmonary tuberculosis. J Clin Microbiol. 2012;50(6):2096-9.

20. Nour EMM, Saeed EMA, Zaki AZSA, Saeed ENS. Specificity of sputum smear compared to culture in diagnosis of pulmonary tuberculosis. World Med Sci. 2011;6(3):121-5. 